\title{
Muslims in Medieval Inquisitorial Thought: Nicolau Eymeric and His Contexts
}

\author{
Michael D. Bailey \\ Department of History, Iowa State University, Ames, Iowa, USA \\ Email: mdbailey@iastate.edu
}

\begin{abstract}
This article analyzes the scant treatment of Muslims in medieval inquisitorial thought, focusing mainly on the late fourteenth-century Aragonese inquisitor Nicolau Eymeric's Directorium inquisitorum (1376). It argues for four contexts in which to understand his engagement with Islam. First, as background, is a longstanding Christian (although not inquisitorial) tradition categorizing Islam as a heresy, with which he did not substantially engage. Second is his own goal to extend inquisitorial authority to new subjects, in which he drew on previous inquisitorial thought about Jews. The third involves conflicts between church officials and the Crown of Aragon about jurisdiction over non-Christian subjects. The fourth centers on the supposition that he did not view Muslims living within Christendom as an especially covert or insidious threat requiring special investigation to uncover, which speaks to how he and other inquisitors viewed their role and the nature of the threats they aimed to counter. In broad terms, this article contributes to our understanding of one important way in which medieval Christianity engaged with other religions. It also provides a basis for understanding later developments in early modern Europe.
\end{abstract}

The early modern Spanish Inquisition famously concerned itself with Muslims and especially Moriscos, converts to Christianity who were perpetually suspected of relapsing to their original faith. ${ }^{1}$ Yet as medieval inquisitorial thought developed, primarily in the thirteenth and fourteenth centuries, Muslims figured in it hardly at all. The late fourteenth-century Aragonese inquisitor Nicolau Eymeric, who helped lay the intellectual and institutional foundations for the later Spanish Inquisition, was the first medieval theorist to discuss inquisitorial jurisdiction over Muslims at any length, and he still treated this issue mainly as a subsidiary category to jurisdiction over Jews.

This relative lack of medieval inquisitorial attention to Muslims is in some ways unsurprising. Inquisitors existed to police the Christian faith, while Islam was a separate

Thanks to Thomas Burman and Robin Vose for commenting on early versions of this article, to Sean Field for comments that helped shape the penultimate version, and to John Arnold and Tamar Herzig for help with specific details.

${ }^{1}$ E.g., Stephen Haliczer, Inquisition and Society in the Kingdom of Valencia, 1478-1834 (Berkeley: University of California Press, 1990), esp. chap. 6; and L. P. Harvey, Muslims in Spain 1500-1614 (Chicago: University of Chicago Press, 2005), esp. chap. 4.

(C) The Author(s), 2021. Published by Cambridge University Press on behalf of American Society of Church History. This is an Open Access article, distributed under the terms of the Creative Commons Attribution licence (http://creative commons.org/licenses/by/4.0/), which permits unrestricted re-use, distribution, and reproduction in any medium, provided the original work is properly cited. 
religion; or rather, since the modern concept of "religion" does not fully pertain to the Middle Ages, and certainly not to medieval uses of religio, ${ }^{2}$ it constituted a different "law." The medieval church's own canon law never directly categorized Muslims as heretics. ${ }^{3}$ Within inquisitorial thought, one treatise from the mid-thirteenth century specifically defined heretics as those who had been received into the Christian faith through baptism and then knowingly rejected it. Those who had never been baptized were either Jews or heathens (gentiles), into which category Muslims would presumably fall. ${ }^{4}$

Some interesting conclusions can nevertheless be teased out of medieval inquisitors' reticent treatment of Muslims. This matters for our understanding both of how medieval Christian authorities engaged with other religions and how later frameworks of persecution developed. I should note that my analysis will not delve into actual Christian-Muslim interactions, either through inquisitorial courts or via other mechanisms. ${ }^{5}$ As David Nirenberg has stressed, Christian conceptions of Islam were typically quite disconnected from actual experiences with Muslims. ${ }^{6}$ My focus will therefore remain on inquisitorial theorizing about Muslims (as well as Jews), albeit grounded, at points, in certain social realities. I will also necessarily focus mainly on the inquisitorial theorist who dealt most extensively with the matter of Islam, the aforementioned Nicolau Eymeric.

Eymeric is often regarded as a kind of culminating figure in medieval inquisitorial thought, especially as it developed through a sequence of handbooks and manuals for inquisitors written during the thirteenth and fourteenth centuries. ${ }^{7}$ This reputation rests mainly on his encyclopedic Directorium inquisitorum, completed in 1376. Here he discussed Muslims in two related sections (questiones). One dealt with the issue of conversion: of Christians who might convert to Islam but, more practically, of Muslims

\footnotetext{
${ }^{2}$ Christine Caldwell Ames, "Medieval Religious, Religions, Religion," History Compass 10, no. 4 (2012): 334-352. See also Brent Nongbri, Before Religion: A History of a Modern Concept (New Haven, Conn.: Yale University Press, 2013), esp. 53-84.

${ }^{3}$ Benjamin Z. Kedar, "De Iudeis et Sarracenis: On the Categorization of Muslims in Medieval Canon Law," in Studia in honorem eminentissimi cardinalis Alphonsi M. Stickler, ed. Rosalio José Castillo Lara (Rome: Libreria Ateneo Salesiano, 1992), 207-213, at 212. More comprehensively, see David M. Freidenreich, "Muslims in Western Canon Law, 1000-1500," in Christian-Muslim Relations: A Bibliographical History, vol. 3, (1050-1200), ed. David Thomas and Alexander Mallett, History of Christian-Muslim Relations 15 (Leiden: Brill, 2011), 41-68.

${ }^{4}$ De inquisitione hereticorum, long attributed, albeit "rather precariously," to the German Franciscan David of Augsburg. See Wilhelm Preger, ed., Der Tractat des David von Augsburg über die Waldensier (Munich: Verlag der königlichen Akademie, 1878), 24: "Heretici quippe dicuntur, qui fidem per sacramentum baptismi susceperunt et perverse senciendo abiciunt. Nam qui nec baptismum nec fidem katholicam aliquando susceperunt, aut gentiles dicuntur aut Iudei." On attribution and dating, see Lucy J. Sackville, Heresy and Heretics in the Thirteenth Century: The Textual Representations (York: York Medieval Press, 2011), 139.

${ }^{5}$ On inquisition, see Paola Tartakoff, Between Christian and Jew: Conversion and Inquisition in the Crown of Aragon, 1250-1391 (Philadelphia: University of Pennsylvania Press, 2012), generally focusing on Jews, but see 136-137 on the similarity of Jewish and Muslim experience. On other interactions, see Robin Vose, Dominicans, Muslims and Jews in the Medieval Crown of Aragon (Cambridge: Cambridge University Press, 2009); and Olivia Remie Constable, To Live Like a Moor: Christian Perceptions of Muslim Identity in Medieval and Early Modern Spain (Philadelphia: University of Pennsylvania Press, 2018).

${ }^{6}$ David Nirenberg, "Christendom and Islam," in The Cambridge History of Christianity, vol. 4, Christianity in Western Europe c. 1100-c. 1500, ed. Miri Rubin and Walter Simons (Cambridge: Cambridge University Press, 2009), 149-169, esp. 149, 163.

${ }^{7}$ Derek Hill, Inquisition in the Fourteenth Century: The Manuals of Bernard Gui and Nicholas Eymerich (York: York Medieval Press, 2019), 1.
} 
who became Christian and then might backslide. This followed a similar section that addressed Jews. The other section presented a variety of ways that both Jews and Muslims could be subject to inquisitors even within the practice of their own faith. Because of Directorium's later influence, and because it largely summarizes Eymeric's own thinking, I will mainly address this text, although I will touch on some of his other works as well. ${ }^{8}$

There is a tendency, rooted in the French scholar Antoine Dondaine's pioneering analysis, to see inquisitorial manuals developing along a steady trajectory from simple and pragmatic collections in the mid-thirteenth century to expansive and systematic treatises in the fourteenth. ${ }^{9}$ From that perspective, one might conclude that Eymeric addressed Islam more than any earlier inquisitorial writer simply because he sought to develop a more complete statement about the full extent of inquisitors' powers. As we will see, he definitely expanded upon earlier arguments for their authority over Jews, both as converts and for other reasons. Lucy Sackville has persuasively argued, however, that it is better to approach inquisitorial literature in terms of its specific contexts rather than through any overarching teleological framework. ${ }^{10}$ With that in mind, I will present four different contexts that can inform our understanding of Eymeric's treatment of Muslims.

The first context is quite broad and provides a backdrop against which his approach to Islam must be viewed. While Muslims were never categorized as heretics in medieval canon law, they were frequently castigated as such in Christian polemic. This tradition did not powerfully influence inquisitorial thought, but it was not entirely unavailable to inquisitors. That Eymeric never mentioned it reinforces the argument that his engagement with Islam arose from more specific concerns, not some encyclopedic impulse.

The next two contexts reflect more immediate intellectual and socio-political frameworks within which Eymeric developed his thinking about Muslims. One was his wellknown desire to expand inquisitors' authority over new groups and new categories of activity. ${ }^{11}$ Here he built on already established arguments for inquisitorial authority over Jews. The other entailed jurisdictional confrontations between church officials, particularly inquisitors, and the Crown of Aragon itself concerning their respective authority over non-Christians. Jews and Muslims were both considered to be the special "treasure" of the crown, and monarchs jealously guarded their direct authority over them. ${ }^{12}$ Although Jews were less numerous, they were by far the richer part of that treasure, which, I will suggest, was one reason Eymeric continued to focus mainly on them, even as he expanded his analysis to include Muslims.

For my final context, I will return to a broader perspective-and perhaps a bit of teleology. As processes of inquisition evolved over the thirteenth and fourteenth centuries, they came to focus increasingly on the interior state of the heretical suspect. From a

\footnotetext{
${ }^{8}$ In the absence of a full modern edition, I have used the widely available early modern edition by the canon lawyer Francisco Peña.

${ }^{9}$ Antoine Dondaine, "Le manuel de l'Inquisiteur (1230-1330)," Archivum Fratrum Praedicatorum 17 (1947): 85-194; and reprinted in Antoine Dondaine, Les hérésies et l'Inquisition, XIIe-XIIIe siècles: Documents et études, ed. Yves Dossat (Aldershot: Variorum, 1990).

${ }^{10}$ Lucy J. Sackville, “The Inquisitor's Manual at Work," Viator 44, no. 1 (2013): 201-216.

${ }^{11}$ See esp. Hill, Inquisition in the Fourteenth Century.

${ }^{12}$ David Nirenberg, Communities of Violence: Persecution of Minorities in the Middle Ages, rev. ed. (Princeton, N.J.: Princeton University Press, 2015), 23-30. For Muslims in particular, see John Boswell, The Royal Treasure: Muslim Communities Under the Crown of Aragon in the Fourteenth Century (New Haven, Conn.: Yale University Press, 1977).
} 
mechanism designed to prosecute preconceived groups (real or imagined) engaging in set forms of heretical behavior, inquisition evolved into a means to investigate, and in many ways to construct, hidden interior worlds of belief. ${ }^{13}$ While other factors motivated Eymeric to include Islam explicitly in his discussion of inquisitorial jurisdiction, this development, I will suggest, served to blunt his interest somewhat. Although the evidence is slightly elusive, certain passages in his manual show why he did not think that Muslims presented the same threat of hidden corruption for surrounding Christian populations as did Jews. Inquisitors, therefore, did not need to scrutinize them or their practices nearly so carefully.

\section{Islam as a Christian Heresy}

Some Christian authorities categorized Islam as a heresy almost from its beginnings. The first to do so was the Syrian monk John of Damascus (ca. 675-749), who had intimate knowledge of Muslim beliefs due to this previous service at the Umayyad court. ${ }^{14}$ $\mathrm{He}$ addressed Islam in one long chapter of his Concerning Heresies (Peri aireseon, known as De haeresibus in the West). ${ }^{15}$ Here he introduced what became an often-repeated Christian assertion: that Muhammad was instructed in monotheism by a heretical Christian monk, an Arian in John's account. Other Eastern Christian writers followed in this vein, including the historian Theophanes, whose important Chronographia was translated into Latin in the ninth century (while John's De haeresibus was only translated in the thirteenth). ${ }^{16}$

Much more could be said of this Eastern tradition, but my focus here is on the Latin West. Perhaps the first mention of Muslims as heretics made by a Western writer is found in the sermons of Ademar of Chabannes (d. 1034), ${ }^{17}$ but most experts agree that Latin Christendom did not really engage conceptually with Islam until the twelfth century in the wake of the First Crusade. Expanding Christian control over former Muslim territories in southern Italy and Iberia also played an important role. ${ }^{18}$ Some

\footnotetext{
${ }^{13}$ John H. Arnold, Inquisition and Power: Catharism and the Confessing Subject in Medieval Languedoc (Philadelphia: University of Pennsylvania Press, 2001), chaps. 1-3; and Peter Biller, "Deep is the Heart of Man, and Inscrutable': Signs of Heresy in Medieval Languedoc," in Text and Controversy from Wyclif to Bale: Essays in Honour of Anne Hudson, ed. Helen Barr and Ann M. Hutchison (Turnhout: Brepols, 2005), 267-280.

${ }^{14}$ Daniel J. Sahas, John of Damascus on Islam: The "Heresy of the Ishmaelites" (Leiden: Brill, 1972), 45-47; and John of Damascus, Écrits sur l'Islam, commentary and trans. Raymond Le Coz (Paris: Cerf, 1992), 49-54.

${ }^{15}$ I have used the edition and translation of this chapter in Sahas, John of Damascus on Islam, 132-141. For full edition, see Bonifatius Kotter, ed., Die Schriften des Johannes von Damaskos, vol. 4, Liber de haeresibus, Patristische Texte und Studien 22 (Berlin: De Gruyter, 1981).

${ }^{16}$ The Chronicle of Theophanes the Confessor, trans. Cyril Mango and Roger Scott, with Geoffrey Greatrex (Oxford: Oxford University Press, 1997), 464-465. On Theophanes's and John's translation into Latin, see, respectively, John V. Tolan, Saracens: Islam in the Medieval European Imagination (New York: Columbia University Press, 2002), 104; and Kedar, “De Iudeis et Sarracenis," 211.

${ }^{17}$ Michael Frassetto, "The Image of the Saracen as Heretic in the Sermons of Ademar of Chabannes," in Western Views of Islam in Medieval and Early Modern Europe: Perception of Other, ed. David R. Blanks and Michael Frassetto (New York: Palgrave, 1999), 83-96; and Michael Frassetto, "Pagans, Heretics, Saracens, and Jews in the Sermons of Ademar of Chabannes," in Heresy and the Persecuting Society in the Middle Ages: Essays on the Work of R. I. Moore, ed. Michael Frassetto, Studies in the History of Christian Traditions 129 (Leiden: Brill, 2006), 73-91, esp. 78-80.

${ }^{18}$ On the small but remarkable corpus of Iberian Mozarabic texts, see Thomas E. Burman, Religious Polemic and the Intellectual History of the Mozarabs, c. 1050-1200, Studies in Intellectual History 52 (Leiden: Brill, 1994).
} 
have further set this new intellectual engagement with Islam in the context of the post-Gregorian reordering of Christian society itself. ${ }^{19}$ Whatever their motivations, several significant twelfth-century writers continued to label Islam as a heresy, although they also recognized that this categorization was debatable.

While a number of northern European writers described Islam as a heresy in the early $1100 \mathrm{~s}^{20}$ the most influential depiction came from a former Iberian Jew. ${ }^{21}$ Petrus Alfonsi, born Moses Sephardi, converted to Christianity in 1106 and soon thereafter wrote Dialogus contra Iudaeos. ${ }^{22}$ Within this work, he created an occasion to discuss Islam when he had his Jewish interlocutor ask why he chose to convert to Christianity rather than to the faith (fidem) of the Saracens, under whose rule he had been raised. ${ }^{23}$ Petrus responded with the by now time-honored position that Muhammad had been instructed by heretical Christians, here Jacobites rather than Arians, and also by Jews who "held the law of Moses heretically." ${ }^{24}$ Thus Islam was grounded in heresy against two traditions. The Dialogus proved extremely popular, surviving in some eighty known manuscripts. ${ }^{25}$

While the relatively brief account of Islam as a heresy in Dialogus contra Iudaeos circulated widely, the most extensive treatment of this point in the twelfth century came from another "Petrus": Peter the Venerable, abbot of Cluny. Like Petrus Alfonsi, he initially addressed the "Mohammedan heresy" (Mahumetica heresis) in a treatise against the Jews. ${ }^{26}$ He then wrote two works directed exclusively against Islam, first the relatively brief Summa totius haeresis Saracenorum and then the expansive Contra sectam Saracenorum. ${ }^{27}$

\footnotetext{
${ }^{19}$ Dominique Iogna-Prat, Order and Exclusion: Cluny and Christendom Face Heresy, Judaism, and Islam (1000-1150), trans. Graham Robert Edwards (Ithaca, N.Y.: Cornell University Press, 2002).

${ }^{20}$ Tolan, Saracens, 137-147; and, focused on just one text, John Tolan, "Antihagiography: Embrico of Mainz's Vita Mahumeti," Journal of Medieval History 22, no. 1 (1996): 25-41.

${ }^{21}$ On his "converso" identity, see David A. Wacks, "Conflicted Identity and Colonial Adaptation in Petrus Alfonsi's Dialogus contra Judaeos and Disciplina clericalis," in Marginal Voices: Studies in Converso Literature of Medieval and Golden Age Spain, ed. Amy Aronson-Friedman and Gregory B. Kaplan, Medieval and Early Modern Iberian World 46 (Leiden: Brill, 2012), 69-89.

${ }^{22}$ Latin edition and Spanish translation in Petrus Alfonsi, Diálogo contra los Judios, ed. Klaus-Peter Mieth, trans. Esperanza Ducay (Huesca: Instituto de Estudios Altoaragoneses, 1996) (hereafter cited as Alfonsi, Dialogus when referring to the original text); and English translation in Petrus Alfonsi, Dialogue Against the Jews, trans. Irven M. Resnick, Fathers of the Church: Mediaeval Continuation 8 (Washington, D.C.: Catholic University of America Press, 2006) (hereafter cited as Resnick, Dialogue when referring to the translation).

${ }^{23}$ Alfonsi, Dialogus, 91; and Resnick, Dialogue, 146. For analysis, see John Tolan, Petrus Alfonsi and His Medieval Readers (Gainesville: University Press of Florida, 1993), 27-33; and Tolan, Saracens, 49-54.

${ }^{24}$ Alfonsi, Dialogus, 95; and Resnick, Dialogue, 151-152 (although I have modified it here).

${ }^{25}$ Resnick, introduction to Dialogue Against the Jews, 26; and Tolan, Petrus Alfonsi, 98-103, 108-110, 182-198.

${ }^{26}$ Petrus Venerabilis, Adversus Iudeorum inveteratam duritiem, ed. Yvonne Friedman, Corpus Christianorum Continuatio Mediaevalis 58 (Turnhout: Brepols, 1985), 108; and Peter the Venerable, Against the Inveterate Obduracy of the Jews, trans. Irven M. Resnick, Fathers of the Church: Mediaeval Continuation 14 (Washington, D.C.: Catholic University of America Press, 2013), 190.

${ }^{27}$ Scholarly editions and German translations of both Summa totius haeresis Saracenorum and Contra sectam Saracenorum in Petrus Venerabilis, Schriften zum Islam, ed. and trans. Reinhold Glei, Corpus Islamo-Christianum Series Latina 1 (Altenberge: CIS-Verlag, 1985) (hereafter cited as Peter the Venerable, Summa or Contra sectam when referring to the original texts, respectively); and English translations in Peter the Venerable, Writings against the Saracens, trans. Irven M. Resnick, Fathers of the Church:
} 
Much has been written about Peter's extensive engagement with Islam, which also included commissioning the first Latin translation of the Qur'an. ${ }^{28}$ Here we need only note that, in his Summa, he, too, described Muhammad as having been instructed by both Jews and a heretical Christian monk-now a Nestorian named Sergius. ${ }^{29}$ Indeed, Peter presented Islam as the culmination of all earlier heresies, with Muhammad "vomiting back up almost all the dregs of previous heresies, which he had swallowed under the devil's instruction." ${ }^{30}$ Importantly, however, he also questioned whether Muslims were really best identified as heretics. "Although I would name them heretics because they believe some things with us," he wrote, "in most things they differ from us, so perhaps more correctly I should name them pagans or heathens, which is worse." ${ }^{11} \mathrm{He}$ repeated this equivocation in Contra sectam Saracenorum, noting that "whether Muhammad's error ought to be called heresy, and his followers called heretics or heathens, I do not discern sufficiently." Instead, he advised his readers to "choose, therefore, what you prefer." 32

Through Peter we can see a Western European clergyman thinking about Islam in relation not just to Judaism but to other Christian heresies, and not exclusively those of centuries past. Peter's other great work of polemic in defense of Christian orthodoxy was Contra Petrobrusianos hereticos, and his consideration of that contemporary heretical threat may have influenced his approach to Islam as well. ${ }^{33}$ Despite his overall standing in the religious world of the twelfth century, however, his treatises on Islam do not appear to have circulated widely. ${ }^{34}$ Even when his positions were known, his successors often exercised the choice he offered and labeled Muslims as pagans rather than heretics.

At the end of the twelfth century, for example, Alain of Lille was probably familiar with Peter the Venerable's writings on Islam, at least indirectly. ${ }^{35}$ When he addressed Muslims alongside heretics and Jews as part of an all-encompassing defense of Christianity in his De fide catholica, however, he titled the section on Muslims

Mediaeval Continuation 16 (Washington, D.C.: Catholic University of America Press, 2016) (hereafter cited as Resnick, Writings when referring to the translation).

${ }^{28}$ For somewhat opposed accounts, see Iogna-Prat, Order and Exclusion, 265-357; and Scott G. Bruce, Cluny and the Muslims of La Garde-Freinet: Hagiography and the Problem of Islam in Europe (Ithaca, N.Y.: Cornell University Press, 2015), 70-129. On the Qur'an translation, Thomas E. Burman, Reading the Qur'an in Latin Christendom, 1140-1560 (Philadelphia: University of Pennsylvania Press, 2007), esp. 60-87.

${ }^{29}$ Peter the Venerable, Summa, 8; and Resnick, Writings, 39.

${ }^{30}$ Peter the Venerable, Summa, 10-12; and Resnick, Writings, 43.

${ }^{31}$ Peter the Venerable, Summa, 14; and Resnick, Writings, 46. Labeling Islam as a form of paganism also had deep roots in Christian traditions; see Tolan, Saracens, 105.

${ }^{32}$ Peter the Venerable, Contra sectam, 50; and Resnick, Writings, 68-69.

${ }^{33}$ Iogna-Prat, Order and Exclusion; John Tolan, "Peter the Venerable on the 'Diabolical Heresy of the Saracens,"' in The Devil, Heresy, and Witchcraft in the Middle Ages: Essays in Honor of Jeffrey B. Russell, ed. Alberto Ferreiro (Leiden: Brill, 1998), 345-367, esp. 346, 348-350; and R. I. Moore, "Building the Ramparts: Heresy and Social Change in the Time of Peter the Venerable," in Musulmanes y cristianos en Hispania durante las conquistas de los siglos XII y XIII, ed. Miquel Barceló and José Martínez Gázquez (Bellaterra: Universitat Autònoma de Barcelona, 2005), 51-61.

${ }^{34}$ Only a single complete manuscript copy is known to have survived for both his Summa and Contra sectam, although two later partial copies of the Summa are also known. See Resnick, introduction to Writings against the Saracens, 16-17; and Tolan, Saracens, 164.

${ }^{35}$ Marie-Thérèse d'Alverny, "Alain de Lille et l'Islam: Le Contra Paganos," in Islam et chrétiens du Midi (XIIe-XIVe s.), Cahiers de Fanjeaux 18 (Toulouse: Privat, 1983), 301-350, at 307. 
"Contra paganos," and he referred to them as pagans throughout. ${ }^{36}$ In only one place did he break with that decision, noting that, like the Jews, the "aforesaid heretics" (Muslims) tended to deride Christianity for its reliance on devotional images. ${ }^{37}$

While the categorization of Islam as a heresy was muted after the twelfth century, it did not disappear. Indeed, in the early thirteenth century, at least one Western writer with considerable exposure to Islam bemoaned the fact that it was not commonly labeled a heresy. In the early 1220s, the German cleric Oliver of Paderborn described Islamic beliefs and practices in his account of the Fifth Crusade, Historia Damiatina. There he noted that, particularly because Muslims accepted Christ's more-than-human nature but still denied his divinity, "truly they ought to be called heretics rather than Saracens, but the use of the false name prevails." 38 Around 1260, the Franciscan bishop Benedict of Alignan appears to have conflated Muslims and heretics in his Tractatus fidei contra diversos errores, at least in terms of justification for crusades against them. ${ }^{39}$

Benedict's Tractatus brings us into the mid-thirteenth century, when papally appointed inquisitors and the first inquisitorial manuals also appeared. Compared to these sources, the mainly twelfth-century texts surveyed above tended to deploy the term heresy "untechnically," as one still influential survey would have it. I would contend, however, that they did not deploy it "casually and carelessly." 40 There were clear reasons for them to consider Islam as a heretical deviation from Christianity, and Peter the Venerable, especially, thought carefully about how it should best be categorized. Nevertheless, these works were all broad polemics, not narrower considerations of Islam's status under Christian law.

Regarding that legal status, I have already noted that Islam was never categorized as a heresy in Christian law. ${ }^{41}$ Indeed, canon law presented little systematic treatment of Muslims prior to the thirteenth century. ${ }^{42}$ That began to change when Pope Gregory IX commissioned the first great extension of canon law, the so-called Liber extra or Decretals. Compiled under the direction of the Dominican Raymond of Peñafort, this collection was issued in 1234. Drawing together previous legislation, it included a substantial section De Iudeis, Sarracenis, et eorum servis. ${ }^{43}$ Here Muslims appeared as a discrete category, linked to Jews but not to heretics.

\footnotetext{
${ }^{36}$ Edition in d'Alverny, "Alain de Lille," 325-350.

${ }^{37}$ D'Alverny, "Alain de Lille," 344: "Nobis etiam insultant predicti heretici cum Iudeis, quia habemus ymagines in ecclesiis nostris et sculptilia." Even here, d'Alverny's apparatus indicates that one manuscript reads "pagani" for "heretici," and the term is omitted entirely in several others.

38"Unde verius heretici quam Sarraceni nominari deberent, sed usus falsi nominis prevaluit." Edition in Hermann Hoogeweg, Die Schriften des Kölner Domscholasters, späteren Bishofs von Paderborn und Kardinal-Bishofs von S. Sabina Oliverus (Tübingen: Litterarischer Verein in Stuttgart, 1894), 161-282, quotation at 204 (Historia Damiatia 24); and translated as Oliver of Paderborn, The Capture of Damietta, trans. John J. Gavigan (Philadelphia: University of Pennsylvania Press, 1948), 37. For context, see Jessalynn Bird, "Crusade and Conversion after the Fourth Lateran Council (1215): Oliver of Paderborn's and James of Vitry's Missions to Muslims Reconsidered," Essays in Medieval Studies 21 (2004): 23-48.

${ }^{39}$ Kurt Villads Jensen, "War Against Muslims According to Benedict of Alignano, OFM," Archivum Franciscanum Historicum 89 (1996): 181-195, at 186. John H. Arnold, "Benedict of Alignan's Tractatus fidei contra diversos errores: A Neglected Anti-Heresy Treatise," Journal of Medieval History 45, no. 1 (2019): 20-54, at 26n24, argues that Benedict regarded Muslims as being "in error" but not strictly heretics

${ }^{40}$ Norman Daniel, Islam and the West: The Making of an Image, rev. ed. (Oxford: Oneworld, 1993), 213.

${ }^{41}$ See $\mathrm{n} 3$ above.

${ }^{42}$ Freidenreich, "Muslims in Western Canon Law," 41.

${ }^{43}$ Emil Friedberg, ed., Corpus iuris canonici, 2 vols. (1879-1881; repr., Graz: Akademische Druck- und Verlagsanstalt, 1959), 2:771-778 (X 5.6); and Robert Chazan, ed., Church, State, and Jew in the Middle Ages
} 
Both Jews and Saracens were, however, implicitly associated with heretics, schismatics, and apostates, all covered in the next three sections of Gregory's Decretals. ${ }^{44}$ Moreover, as Raymond later commented in his Summa de poenitentia et matrimonio, this section of the Decretals also established that church law extended to non-Christians under certain circumstances. ${ }^{45}$ For example, neither Jews nor Muslims should be allowed to disparage Christ or the crucifixion. ${ }^{46}$ Such claims were further developed during the pontificate of Innocent IV (1234-1254). ${ }^{47}$ Indeed, Innocent drew on this legislation when, in 1254, he enjoined Dominican and Franciscan inquisitors in Italy to proceed not only against heretics and their supporters (fautores) but also against non-Christians who either had carnal relations with Christians or showed contempt for the Christian faith. ${ }^{48}$

The older tradition of labeling Islam a heresy as a polemical if not legalistic statement also had at least some resonance in inquisitorial thought, although what conclusions can be drawn from this are unclear. The so-called Passau Anonymous, composed in central Europe in the 1260s, is a ramshackle assemblage. While its compiler, who was almost certainly an inquisitor, appears to have had direct experience only with Waldensian heretics, he intended his collection to help defend the church from many enemies: "Jews, heretics, pagans, and false Christians." 49 The text exists in a bewildering number of variants, but many include a brief section derived from Petrus Alfonsi's treatment of Islam in Dialogus contra Iudaeos. ${ }^{50}$ It repeated the old saws that Muhammed was instructed in his faith by Christian heretics (here Jacobites) and by heretical Jews.

What use inquisitors in central Europe might have made of this text is difficult to see. There were no Muslim communities in the region at this time. ${ }^{51}$ Moreover, even in Christian lands that had considerable Muslim populations, throughout the thirteenth century Dominicans and members of other religious orders who regularly staffed papal inquisitions operated toward non-Christians primarily as missionaries seeking

(New York: Behrman, 1980), 28-35. The section originated in Bernard of Pavia's late twelfth-century Breviarium extravagantium.

${ }^{44}$ Friedberg, Corpus iuris canonici, 2:778-792 (X 5.7-9).

${ }^{45}$ Chazan, Church, State, and Jew, 40.

${ }^{46}$ Friedberg, Corpus iuris canonici, 2:776-777 (X.5.6.15).

${ }^{47}$ James Muldoon, Popes, Lawyers, and Infidels: The Church and the Non-Christian World, 1250-1550 (Philadelphia: University of Pennsylvania Press, 1979), 9-11.

${ }^{48}$ Vasil Bivolarov, Inquisitoren-Handbücher: Papsturkunden und juristische Gutachten aus dem 13. Jahrhundert mit Edition des Consilium von Guido Fulcodii (Wiesbaden: Harrassowitz, 2014), 73; and Giuseppe Rossini, "Un piccolo codice 'inquisitoriale' del convento di S. Francesco di Rimini nella Biblioteca Comunale di Faenza," Studi romagnoli 2 (1951): 137-150, at 145-146.

${ }^{49}$ Alexander Patschovsky, Der Passauer Anonymus: Ein Sammelwerk über Ketzer, Juden, Antichrist aus der Mitte des 13. Jahrhunderts, Schriften der Monumenta Germaniae Historica 22 (Stuttgart: Hiersemann, 1968), 112; and, on dating and identification of the author as an inquisitor, see 138-150.

${ }^{50}$ Patschovsky, Passauer Anonymus, 28. A transcription of this section is available in Margaret Annie Eugenie Nickson, "A Critical Edition of the Treatise on Heresy Ascribed to Pseudo-Reinerius, with an Historical Introduction" (PhD diss., University of London, 1960), 180-184.

${ }^{51}$ For a parallel situation reflected in pastoral manuals, see Deeana Copeland Klepper, "Disentangling Heretics, Jews, and Muslims: Imagining Infidels in Late Medieval Pastoral Manuals," in Late Medieval Heresy: New Perspectives, Studies in Honor of Robert E. Lerner, ed. Michael D. Bailey and Sean L. Field (York: York Medieval Press, 2018), 137-156. 
conversion, not as magistrates set on punishing erroneous beliefs. ${ }^{52}$ Under civil law, too, Muslim populations living in Christian lands were regularly accorded the status of a protected minority, as were Jews. ${ }^{53}$ Nevertheless, some perception of Muslims as heretics still persisted, creating a "tension" in terms of their accommodation within Christian law codes. ${ }^{54}$ The Passau Anonymous seems to show that such tension lurked in at least some corners of inquisitorial thought as well.

\section{Nicolau Eymeric on Muslims and Jews}

Papally appointed inquisitors began operating in Europe following Pope Gregory IX's bull Ille humani generis, first issued in 1231, and standing inquisitorial tribunals emerged in southern France in the wake of the Albigensian Crusade. ${ }^{55}$ These developments necessitated a rapid codification of procedures, and almost immediately a new genre developed, that of the inquisitor's manual. ${ }^{56}$ The first of these is generally held to be a set of guidelines for inquisitorial operations produced under the direction of Raymond of Peñafort at the Council of Tarragona in $1242 .{ }^{57}$ As we have seen, just a decade earlier Raymond had supervised the expansion of canon law in the Decretals that had included a section on Muslims. He made no reference to them in his instructions for inquisitors, however. One year later, a set of guidelines emerging from the Council of Narbonne did refer to Muslims but only as the object of a potential penance that could be prescribed for heretics. It advised inquisitors that convicted heretics might be "obliged to defend the faith and church for a fixed number of years, months, or days, with arms and at their own expense... against Saracens." 58

Aside from the curious case of the Passau Anonymous, inquisitorial literature remained largely silent about Islam throughout the thirteenth century. In the midfourteenth century, the Carmelite bishop, theologian, and sometime inquisitor Guido Terreni wrote his Summa de haeresibus. In one manuscript, a list of "Twenty-Five Errors of the Saracens" is found appended to this work. However, while the Summa itself dates to around 1340, the authorship, and hence dating, of this list remains uncertain. If it was not written by Terreni, then it could have been composed as late as 1455 , when the single manuscript in which it is found was copied. ${ }^{59}$ In that case, it would reflect the concerns of a later era, which I discuss in my conclusion below. Inquisitorial reluctance to discuss Muslims ended definitively only when Nicolau

\footnotetext{
${ }^{52}$ Tolan, Saracens, esp. 233-255; and, on the limits of such missionizing, see Vose, Dominicans, Muslims and Jews, esp. 21-59.

${ }^{53}$ Brian A. Catlos, Muslims of Medieval Latin Christendom, c. 1050-1614 (Cambridge: Cambridge University Press, 2014), 360-365.

${ }^{54}$ Tolan, Saracens, 192.

${ }^{55}$ Kurt-Victor Selge, ed., Texte zur Inquisition (Gütersloh: Gerd Mohn, 1967), 45-47.

${ }^{56}$ The fundamental study remains Dondaine, "Manuel." See also Sackville, Heresy and Heretics, 135-153; and Sackville, "Inquisitor's Manual at Work."

${ }^{57}$ See Dondaine, "Manuel," 96-97; edited in Selge, Texte zur Inquisition, 50-59; and translated in John H. Arnold and Peter Biller, eds. and trans., Heresy and Inquisition in France, 1200-1300 (Manchester: Manchester University Press, 2016), 218-229.

${ }^{58}$ Selge, Texte zur Inquisition, 61; and translation modified from Arnold and Biller, Heresy and Inquisition in France, 237.

${ }^{59}$ Cándida Ferrero Hernández, "Los 25 errores de los musulmanes, según el ms. Vat. Lat. 988: Notas sobre su atribución a Guido Terrena," in Guido Terreni, O. Carm. (†1342): Studies and Texts, ed. Alexander Fidora (Barcelona: Fédération Internationale des Instituts d'Études Médiévales, 2015), 269-280.
} 
Eymeric addressed inquisitors' jurisdiction over them in a succession of works in the second half of the fourteenth century.

Eymeric was born in Girona, in northern Catalonia, sometime before $1320 .{ }^{60} \mathrm{He}$ entered the Dominican order in 1334 and studied theology first in Barcelona and then in Paris. In 1352, he was back in Barcelona, teaching. By 1357, he was acting as an inquisitor in the Crown of Aragon. Although the full extent of his authority remains unclear, he was certainly the most important inquisitorial official in Aragon in his day. ${ }^{61}$ He had a tumultuous career to say the least, clashing repeatedly with a succession of Aragonese monarchs, frequently being removed from and reinstated to various offices, and enduring several periods of exile. ${ }^{62}$ It was often while he was relieved of his regular duties that he was able to write some of his major works, particularly Directorium inquisitorum, composed in exile at the papal court in Avignon in 1376.

Although Eymeric is often regarded as marking a culmination of medieval inquisitorial thought, especially through his Directorium, Derek Hill has recently argued that he also represented an important innovation. Previous manuals, including those produced earlier in the fourteenth century, had generally envisioned inquisitors operating against established threats. Thus, in his great manual Practica inquisitionis, completed around 1325, the Toulouse inquisitor Bernard Gui had identified and described at considerable length six major groups against whom inquisitors were regularly empowered to act. Among these were Jews but not Muslims. ${ }^{63}$ Eymeric, however, saw the need for inquisitors to respond dynamically to a series of new and changing threats to the Christian faith. ${ }^{64} \mathrm{He}$ left the nature of these threats open-ended, but his proposed response certainly entailed further expansion of inquisitorial jurisdiction over non-Christians, now explicitly including Muslims.

Inquisitorial jurisdiction over non-Christians occupied Eymeric for much of his career. He first addressed the question at length in a treatise ostensibly devoted to another of his major concerns: whether demonic magicians should be considered heretics. $^{65}$ Since worshiping demons contradicted the basic principle of monotheism

\footnotetext{
${ }^{60}$ The fundamental study of Eymeric's life is Claudia Heimann, Nicolaus Eymerich (vor 1320-1399), praedicator veridicus, inquisitor intrepidus, doctor egregius: Leben und Werk eines Inquisitors (Münster: Aschendorff, 2001). For issues pertinent here, see also Claudia Heimann, "Quis proprie hereticus est? Nicolaus Eymerichs Häresiebegriff und dessen Anwendung auf die Juden," in Praedicatores, inquisitores I: The Dominicans and the Medieval Inquisition, ed. Wolfram Hoyer (Rome: Instituto Storico Domenicano, 2004), 595-624; and Claudia Heimann, "Nicolaus Eymerich OP: Der Inquisitor und die Juden im Aragon des 14. Jahrhunderts," in Dominikaner und Juden / Dominicans and Jews: Personen, Konflikte und Perspektiven vom 13. bis zum 20. Jahrhundert / Personalities, Conflicts, and Perspectives from the 13th to the 20th Century, ed. Elias H. Füllenbach OP and Gianfranco Miletto (Berlin: De Gruyter, 2015), 135-154.

${ }^{61}$ Heimann, Nicolaus Eymerich, 18-19.

${ }^{62}$ In addition to Heimann, Nicolaus Eymerich, see Michael A. Ryan, A Kingdom of Stargazers: Astrology and Authority in the Late Medieval Crown of Aragon (Ithaca, N.Y.: Cornell University Press, 2011), chap. 5.

${ }^{63}$ Bernard Gui, Practica inquisitionis heretice pravitatis, ed. Célestin Douais (Paris: Picard, 1886), 288292 (5.5); and translated in Walter L. Wakefield and Austin P. Evans, eds. and trans., Heresies of the High Middle Ages (New York: Columbia University Press, 1969), 439-444.

${ }^{64}$ Hill, Inquisition in the Fourteenth Century, 172-173.

${ }^{65}$ This aspect of his work has been much studied: see Michael D. Bailey, Fearful Spirits, Reasoned Follies: The Boundaries of Superstition in Late Medieval Europe (Ithaca, N.Y.: Cornell University Press, 2013), 81-94; Julien Véronèse, "Nigromance et hérésie: Le De jurisdictione inquisitorum in et contra christianos demones invocantes (1359) de Nicolas Eymerich (O.P.)," in Penser avec les démons: Démonologues et démonologies (XIIIe-XVIIe siècles), ed. Martine Ostorero and Julien Véronèse, Micrologus' Library 71 (Florence: SISMEL Edizioni del
} 
espoused in Christian, Jewish, and Islamic law alike, investigating the supposed invocation and supplication of demons represented one way for inquisitors to extend their authority over other faiths. Having already written a treatise Contra christianos demones invocantes in 1359, Eymeric wrote a continuation, Contra infideles demones invocantes, probably around $1370 .^{66}$ The full title of this treatise was De iurisdictione ecclesie et inquisitorum contra infideles demones invocantes vel alias fidem catholicam agitantes (On the Jurisdiction of the Church and Inquisitors against Infidels Invoking Demons or Others Disturbing the Catholic Faith), and it actually focused much more on inquisitorial jurisdiction over Jews and other infidels in general than on the specific issue of demonic magic. It also served as a basis for the longest section dealing with non-Christians in the subsequent Directorium, written in $1376 .{ }^{67}$ Still not having had his full say, Eymeric returned to the issue again in his Tractatus brevis super iurisdictione inquisitorum contra infideles fidem catholicam agitantes, written in the $1380 \mathrm{~s}^{68}$

Here we can focus on Directorium, which encapsulated much of Eymeric's thought and was certainly his most influential work. He addressed jurisdiction over non-Christians in three consecutive questiones, numbers 44 to 46 in part 2 of this extensive manual. The first dealt with inquisitors' jurisdiction over Christians who converted to Judaism or over Jews who converted to Christianity and then relapsed to their original faith. Both were to be treated as heretics, as was anyone, Christian or Jew, who might support or defend them. ${ }^{69}$ Here Eymeric drew on well-established precedents in canon law and inquisitorial thought. Already in the twelfth-century Decretum, the fundamental medieval collection of canon law that had preceded the thirteenth-century Decretals of Gregory IX, the church had proclaimed that, while Jews were not to be converted to the Christian faith by force, "once converted they are not permitted to leave it."70 Likewise, Jews who in any way promoted or facilitated the conversion of Christians or the reconversion of former Jews were also subject to inquisitors just as "supporters" (fautores) of any other heresy would be.

The growing concern of ecclesiastical authorities in the thirteenth century over such secret Jewish conniving to win converts is exemplified by the papal decree Turbato corde, first issued by Clement IV in 1267 and then reissued in 1274, 1288, and 1290. Here the pope declared that "exceedingly numerous reprobate Christians. . . have gone over. . . to the rite of the Jews." Dominican and Franciscan inquisitors were enjoined to proceed against such people just as they would against any other heretics,

Galluzzo, 2015); and Pau Castell Granados, “The Inquisitor’s Demons: Nicolau Eymeric's Directorium inquisitorum," in The Science of Demons: Early Modern Authors Facing Witchcraft and the Devil, ed. Jan Machielsen (London: Routledge, 2020), 19-34.

${ }^{66}$ Eymeric's Contra infideles demones invocantes was first identified in Josep Perarnau, “Tres nous tractats de Nicolau Eimeric en un volum de les seves 'Opera omnia' manuscrites procedent de Sant Domènec de Girona," Revista Catalana de Teologia 4, no. 1 (1979): 79-100; analyzed in Heimann, "Quis proprie”; and partially edited in Katelyn Mesler, "The Jurisdiction of Medieval Inquisitors over Jews and Muslims: Nicholas Eymeric's Contra infideles demones invocantes," in The Sacred and the Sinister: Studies in Medieval Religion and Magic, ed. David J. Collins, SJ (University Park: Pennsylvania State University Press, 2019), 163-199.

${ }^{67}$ Eymeric, Directorium inquisitorum, ed. Francisco Peña (Rome, 1587), 352-358 (2.46).

${ }^{68}$ Josep Perarnau i Espelt, "El Tractatus brevis super iurisdictione inquisitorum contra infideles fidem catholicam agitantes de Nicolau Eimeric," Arxiu de Textos Catalans Antics 1 (1982): 79-126, dating at 84; edition 101-125.

${ }^{69}$ Eymeric, Directorium, 348-349 (2.44).

${ }^{70}$ Friedberg, Corpus iuris canonici, 1:161-162 (D. 45 c. 5); and Chazan, Church, State, and Jew, 20-21. 
and Jews "whom you shall have discovered inducing Christians of either sex into their execrable rite" were to be punished "with due penalty."71 These provisions quickly became standard references in inquisitorial literature. They were, for example, cited in the short French manual Doctrina de modo procedendi contra hereticos, written in the late thirteenth century. ${ }^{72}$ In addition, separate, free-standing formulae of interrogation designed for Christian converts to Judaism and former Jews accused of returning to Judaism circulated in conjunction with other inquisitorial literature. ${ }^{73}$ Likewise, collections of papal rulings and other legal opinions regarding inquisitorial jurisdiction over Jews also circulated. One such text, clearly of Italian provenance, began with Turbato corde and concluded with consultations of jurists and magistrates from Bologna, Ferrara, and Padua. ${ }^{74}$

In his first questio regarding non-Christians, therefore, Eymeric did not need to innovate. As his main justification, he presented the bull Turbato corde, which he cited in full. ${ }^{75}$ In his second, parallel questio, he merely extended the same reasoning to Christians who might convert to Islam or Muslim converts to Christianity who might then relapse to their original faith. ${ }^{76}$ This was no innovation either, as the principle was already well established that, for the most part, laws pertaining to Jews could be applied to Muslims as well. ${ }^{77}$ Eymeric merely rendered this principle explicit by offering a separate questio addressing Muslims. He also offered a separate papal decree to support his argument: Gregory XI's bull Admodum dolenter, composed at Eymeric's own urging in $1371 .^{78}$ In it, the pope bemoaned the number of Saracens who had converted to Christianity but then relapsed into their original "impiety" as well as the many Christians supposedly converting to Islam. ${ }^{79}$

While the case of converts was relatively clear-cut, Eymeric addressed other, more complicated circumstances in which both Jews and Muslims, as well as "other infidels," could be considered heretics or otherwise fall under inquisitorial jurisdiction in his third and longest questio on this matter. ${ }^{80} \mathrm{He}$ began with the principle that both Jews and Muslims shared certain articles of faith with Christians, as well as differing

\footnotetext{
${ }^{71}$ Edited in Shlomo Simonsohn, The Apostolic See and the Jews, 8 vols. (Toronto: Pontifical Institute of Mediaeval Studies, 1988-1991), 1:236-237; and translation and analysis in Jeremy Cohen, The Friars and the Jews: The Evolution of Medieval Anti-Judaism (Ithaca, N.Y.: Cornell University Press, 1982), 48-49.

${ }^{72}$ Vatican City, Biblioteca Apostolica Vaticana, Vat. Lat. 3978, fols. 82r-87v, at 87r; and Arnold and Biller, Heresy and Inquisition in France, 287.

${ }^{73}$ See, e.g., Interrogatoria ad iudeos in Vat. Lat. 3978, fol. $53 \mathrm{v}$. On the manuscript as a whole, see Dondaine, "Manuel," 140-154.

${ }^{74}$ Vatican City, Biblioteca Apostolica Vaticana, Vat. Lat. 2648, fols. 64v-66v, where it is surrounded by other inquisitorial literature. See Dondaine, "Manuel," 154-167; and Bivolarov, Inquisitoren-Handbücher, $199-202$.

${ }^{75}$ Eymeric, Directorium, 348-349 (2.44.4).

${ }^{76}$ Eymeric, Directorium, 351-352 (2.45).

${ }^{77}$ See Stefan K. Stantchev, "'Apply to Muslims What Was Said of the Jews': Popes and Canonists Between a Taxonomy of Otherness and Infidelitas," Law and History Review 32, no. 1 (2014): 65-96.

${ }^{78}$ Robin Vose, "Heresy Inquisitions in the Later Middle Ages," in A Companion to Heresy Inquisitions, ed. Donald S. Prudlo, Brill's Companions to the Christian Tradition 85 (Leiden: Brill, 2019) 141-171, at 166.

${ }^{79}$ Eymeric, Directorium, 351-352 (2.45.4); and Magnum Bullarium Romanum [. . .], 19 vols. (Luxemburg, 1727-1757), 1:263.

${ }^{80}$ Eymeric, Directorium, 352-358 (2.46). Mesler, "Jurisdiction of Medieval Inquisitors," 166, notes he drew this section "almost verbatim" from Contra infideles demones invocantes.
} 
from them on many points. Both Jews and Muslims could, therefore, become "heretics" within their own faith if they rejected certain fundamental beliefs. ${ }^{81}$ For a Christian inquisitor, this was of no concern so long as the beliefs in question were not among those held in common with Christianity. In such cases, Christian authorities should "condemn" (reprobare) but nevertheless "tolerate" (tolerare) the lapse as, essentially, no business of theirs. ${ }^{82}$ Where the lapse involved an article of faith common to Christianity as well, however, such as the belief that God created all things, that Christ was born of a virgin (applicable only to Muslims, not Jews), or that one should not invoke and worship demons in magical rites, then Christian inquisitors absolutely could step in and enforce proper faith. ${ }^{83}$

Eymeric was relatively innovative in bringing all this material together and explicitly applying it to Muslims. Such principles were not, however, entirely without precedents in inquisitorial thought regarding Jews. The mid-thirteenth-century manual De inquisicione hereticorum had declared that Jews could be considered heretics if they "corrupted" teachings of the Old Testament in any way (in Christian judgement, of course).$^{84}$ In the early fourteenth century, Bernard Gui argued that inquisitors could seize and burn copies of the Talmud because it contained what Christian authorities deemed to be errors, and indeed "horrors," contradicting the true faith. ${ }^{85}$

There was not, however, complete agreement on these matters even within inquisitorial thought. Just a few years after Gui completed Practica inquisitionis, the Italian jurist Zanchino Ugolini composed his important Tractatus super materia hereticorum (ca. 1330). He echoed Gui and other inquisitorial texts on many points about the Jews, including the right of inquisitors to punish them if they "transgressed" against the laws of their own faith. ${ }^{86}$ Yet especially on this last point, Ugolini was considerably more reserved than Gui. While he felt that inquisitors had a right to pursue such cases, he also argued that church authorities should only act if, by such a violation, Jews did some direct harm to Christians, as through the practice of usury. Even in that case, he concluded, punishment was better left to bishops than to inquisitors, who should only act in direct defense of Christian doctrine, not of Christian society more generally. ${ }^{87}$

Another principle whereby either Jews or Muslims could fall under inquisitorial jurisdiction, only briefly stated by Eymeric but potentially quite sweeping, was very much geared toward the protection of Christian society. It focused on whether they had "impeded" the Christian faith in any way. This might involve blaspheming against Christianity, attempting to lead Christians into some evil actions, or even "openly persecuting" Christians in some fashion. ${ }^{88}$ Again there were precedents, at least in terms of

\footnotetext{
${ }^{81}$ Eymeric, Directorium, 352-353 (2.46.1-3, on Jews), 355 (2.46.12, on Jews and Saracens).

${ }^{82}$ Eymeric, Directorium, 355 (2.46.12).

${ }^{83}$ Eymeric, Directorium, 353 (2.46.4), 355 (2.46.12).

${ }^{84}$ Preger, Tractat des David von Augsburg, 24.

${ }^{85}$ Gui, Practica, 67 (2.48). For an overview of ecclesiastical opposition to the Talmud, see Rebecca Rist, Popes and Jews, 1095-1291 (Oxford: Oxford University Press, 2016), 194-206. The first burning had taken place in France in 1242.

${ }^{86}$ Zanchino Ugolini, Tractatus de haereticis 36, ed. Camillo Campeggi (Rome, 1579), 219-222. On the original text and its variations, see Peter Diehl, "An Inquisitor in Manuscript and in Print: The Tractatus super materia hereticorum of Zanchino Ugolini," in The Book Unbound: Editing and Reading Medieval Manuscripts and Texts, ed. Siân Echard and Stephen Partridge (Toronto: University of Toronto Press, 2004), 58-77.

${ }^{87}$ Ugolini, Tractatus de haereticis 36, p. 221.

${ }^{88}$ Eymeric, Directorium, 354 (2.46.7).
} 
the Jews, in earlier inquisitorial thought. Bernard Gui had justified inquisitors taking action against Jews by arguing that they often sought to harm Christians by praying for their destruction and that they regularly denigrated Christianity by blaspheming or insulting Christ and the Virgin Mary in their writings. ${ }^{89}$ Ugolino agreed that Jews could come under inquisitorial jurisdiction if they showed any "insult" (contumelia) to Christianity, specifically a church, altar, or sacral object, and especially if they tried to impede an inquisitor in his work. ${ }^{90}$

Perhaps most daringly, Eymeric appears to have asserted a principle that had first been advanced, somewhat vaguely, by Innocent IV; namely, that the pope had authority to enforce natural law over all peoples-Christian, Jew, and heathen alike-if their own rulers failed to do so. ${ }^{91}$ In this questio, Eymeric focused mainly on otherwise unspecified heathens (gentiles), and he argued this power naturally devolved onto papally appointed inquisitors. $^{92}$ The only example he provided of such a violation was sodomy, however, and he did not develop the point at any length.

\section{Muslims and Jews Between Church and State}

From the intellectual underpinnings of Eymeric's engagement with Muslims, which built on previous inquisitorial thought regarding Jews, we move to the more immediate, practical context he encountered as he sought to expand inquisitors' jurisdiction over both Muslims and Jews. Here he had to confront the claim of secular powers, above all the Crown of Aragon itself, to similar authority. In the mid to late fourteenth century, the Aragonese crown was locked in a struggle with the church in general and more particularly with the Aragonese inquisition regarding the degree of each institution's control over non-Christian subjects. ${ }^{93}$

This struggle was a personal one for Eymeric. Around 1370, a Catalonian Jew, Astruc de Piera, was accused of invoking demons to perform magic. The Crown of Aragon claimed jurisdiction, but Eymeric appealed to the papal curia, which ruled that the case should be handled by the inquisitor. Eymeric was clearly thrilled with this victory, as he recounted the case in both Directorium and also his later Tractatus brevis super iurisdictione inquisitorum contra infideles. ${ }^{94}$ In fact, the case may have inspired him to write his first major work on inquisitorial jurisdiction over non-Christians, Contra infideles demones invocantes, although he did not mention it directly there (perhaps because the case remained undecided at that time). ${ }^{95}$

In Directorium, Eymeric acknowledged many arguments contending that cases in which either Jews or Saracens acted in some way against the Christian faith should be handled by "temporal lords" rather than bishops or inquisitors. He responded, however, that all such arguments dealt with infractions against the faith more generally, not heresy in particular. He was perfectly ready to admit that non-Christians could offend against Christianity in many ways that did not rise to the level of heresy, and in all of

\footnotetext{
${ }^{89}$ Gui, Practica, 290-292 (5.5.4).

${ }^{90}$ Ugolini, Tractatus de haereticis 36, p. 220.

${ }^{91}$ Muldoon, Popes, Lawyers, and Infidels, 10-11, 47-48.

${ }^{92}$ Eymeric, Directorium, 353 (2.46.6).

${ }^{93}$ Perarnau, "El Tractatus brevis," 79-80; Heimann, "Quis proprie," 621; and Heimann, "Nicolaus Eymerich OP," 146-147.

${ }^{94}$ Eymeric, Directorium, 357-358 (2.46.17); and Eymeric, Tractatus brevis, as presented in Perarnau, "El Tractatus brevis," 120-222.

${ }^{95}$ Perarnau, "El Tractatus brevis," 83; and Mesler, "Jurisdiction of Medieval Inquisitors," 165-166.
} 
these, secular lords could rightly exercise their own jurisdiction. In cases of heresy, however, "it is for ecclesiastical judges to recognize and judge" the crime. Secular authority only became involved when it was needed to execute a punishment decreed by an ecclesiastical court, such as in cases involving the death penalty. ${ }^{96}$

Complications could arise, of course. Eymeric noted that in the Kingdom of Sicily, the monarch had specifically commissioned bishops to punish Muslims who "abused" Christian woman and children. In such cases, the principal example of which was rape, jurisdiction clearly lay with secular authorities, but this did not preclude them from delegating that authority to ecclesiastical officials. This allowed Eymeric to ruminate briefly on the authority bishops could exercise "through their own ordinary power," as opposed to power they might exercise "by commission." 97

Eymeric did his best to present his conclusions as self-evident and grounded in unquestionable ecclesiastical rulings. In fact, however, his positions were not universally accepted even by other churchmen in Aragon. His contemporary and fellow Catalan, the Carmelite Felip Ribot (d. 1391), wrote a Tractatus de haeresi that sharply restricted inquisitorial jurisdiction to Christians alone. Drawing on time-honored definitions, Ribot maintained that only baptized Christians could be categorized as heretics and that Jews, Muslims, or other non-believers living in Christian lands fell solely under the jurisdiction of secular princes, no matter what the nature of their errors or offenses. ${ }^{98}$ In particular, he maintained that the pope, and hence papally appointed inquisitors, had no authority to police heresy within other faiths, even if non-Christians violated a religious tenet that happened to be held in common with Christianity. ${ }^{99}$ His arguments did not extend to converts who then relapsed to their original faith because they were considered to have become irrevocably Christian from the moment of their conversion. Otherwise, however, he maintained that church inquisitors should always defer to temporal lords in cases involving non-Christians. ${ }^{100}$

Although Ribot strongly countered Eymeric's positions, those who have studied his treatise closely do not think that he was responding directly to Eymeric at any point. Rather, they suspect that he, as a clergyman with ties to the royal court, was simply addressing issues that were regularly being raised at the court itself. ${ }^{101}$ Neither does Eymeric appear to have addressed Ribot directly. He was, however, clearly aware that his positions faced considerable contemporary opposition. Already around 1370, he ended Contra infideles demones invocantes with a set of "replies to the arguments of [my] adversaries" that mainly focused on the proper extent of secular authority in these matters. ${ }^{102}$ Later, in the mid-1380s, he ended his Tractatus brevis by addressing papal decrees bearing specifically on the jurisdiction and authority of Aragonese inquisitors against rights claimed by the crown, and he rebuked certain "adversaries of truth" who claimed that the bull Turbato corde, which had extended inquisitorial authority over Jews, had been superseded. ${ }^{103}$

\footnotetext{
${ }^{96}$ Eymeric, Directorium, 354-355 (46.8-11), quote at 355 (46.11).

${ }^{97}$ Eymeric, Directorium, 355 (46.11-12).

${ }^{98}$ Jaume de Puig i Oliver, "El Tractatus de haeresi et de infidelium incredulitate et de horum criminum iudice de Felip Ribot, O. Carm.”, Arxiu des Textos Catalans Antics 1 (1982): 127-190, edition 150-190.

${ }^{99}$ Ribot, Tractatus de haeresi, 172-173.

${ }^{100}$ Ribot, Tractatus de haeresi, 184-185.

${ }^{101}$ Puig, "El Tractatus de haeresi," 147; and Heimann, "Quis proprie," 621.

${ }^{102}$ Eymeric, Contra infideles demones invocantes, as presented in Mesler, "Jurisdiction of Medieval Inquisitors," 193-198.

${ }^{103}$ Eymeric, Tractatus brevis, 122-124.
} 
Eymeric's discussion of inquisitorial jurisdiction over both Jews and Muslims was more systematic, and for Muslims certainly more extensive, than any that had come before. It was driven by his own desire to extend the scope of inquisitorial authority, but it took shape within the context of broader debates in the Crown of Aragon about inquisitorial, and indeed ecclesiastical, jurisdiction versus that of the crown itself over its non-Christian subjects. This more practical political context is also probably why, even though Eymeric addressed Muslims more directly than any earlier inquisitorial theorist, he remained predominantly concerned about Jews. While Muslims were more numerous in the Crown of Aragon, Jewish communities were far richer and so the far more important part of the "royal treasure" that monarchs sought to keep under their control and the church sought to prize loose. ${ }^{104}$ It is surely not coincidental that one of the last points Felip Ribot made in his pro-monarchical De haeresi was that inquisitors should never be allowed to impose "pecuniary" punishments on Jews, leaving that prerogative to the king (Muslims going, as they so often did, unmentioned at this point). ${ }^{105}$

This is not to say that these debates were directly reflective of or necessarily driven by actual inquisitorial practice in the Crown of Aragon. Although Eymeric made much of the case of Astruc de Piera, that seems to have been an isolated incident. What records remain of his inquisitorial activity in Aragon suggest that Jews, to say nothing of Muslims, did not figure heavily in his caseload, and those who did come to his attention typically represented more straightforward cases of converts suspected of relapsing. ${ }^{106}$ In the face of varying levels of royal opposition, an inquisitor's jurisdiction over converts was always the most secure area of his authority. ${ }^{107}$

\section{Muslims as (Not So) Hidden Threat}

A final context in which to situate Eymeric's approach to Muslims is more speculative, but it carries broad implications. It aims to connect one particular facet of his argument to a more generalized development within medieval inquisitorial thought. If correct, it would offer a more conceptual reason why Eymeric continued to focus primarily on Jews rather than Muslims in his discussions of non-Christians, beyond the practical realities of Aragonese politics. It might therefore shed additional light on how Christian authorities envisioned the threat that they imagined Muslims represented for Christian society as a whole.

As I noted in my introduction, scholars of medieval inquisition recognize a growing emphasis over time on the need to root out increasingly covert and insidious forms of heresy rather than to counter the putatively evident heretical groups, such as Cathars or Waldensians, that had initially attracted most inquisitorial attention. ${ }^{108}$ Eymeric certainly reflected this development in his concern to expand inquisitors' jurisdiction over new kinds of heretical behavior, such as the occult practices of demonic magicians,

\footnotetext{
${ }^{104}$ On this dynamic more broadly, see David Abulafia, "The Servitude of Jews and Muslims in the Medieval Mediterranean: Origins and Diffusion," Mélanges de l'École française de Rome: Moyen-Age 112, no. 2 (2000): 687-714.

${ }^{105}$ Ribot, Tractatus de haeresi, 187.

${ }^{106}$ Heimann, "Nicolaus Eymerich OP," 142-148; and Castell Granados, "Inquisitor's Demons," 27.

${ }^{107}$ Mark D. Meyerson, A Jewish Renaissance in Fifteenth-Century Spain (Princeton, N.J.: Princeton University Press, 2004), 41.

${ }^{108}$ See n13 above.
} 
that might threaten to disrupt Christian society in less obvious ways. ${ }^{109}$ An emphasis on heretics' guile and duplicity was also a hallmark of his thinking, as was a certain approval of deviousness on the part of inquisitors themselves to uncover such heresy. ${ }^{110}$

What has this to do with Muslims or Jews, though, both of whom comprised evident and established groups within medieval Aragonese society? For one thing, the overriding inquisitorial focus on Muslim and Jewish converts to Christianity refocused attention away from their public identity and onto their capacity to harbor hidden beliefs. Converts were, of course, publicly Christian. What inquisitors needed to detect was whether they continued to observe any of the rites of their original faith in secret. Let us leave this most common circumstance aside, however, precisely because it would appear to apply equally (in theory, at least) to Muslims and Jews. I want instead to explore an element of Eymeric's argument that suggests inquisitors needed to police Jews as Jews more closely than Muslims as Muslims. Ironically, this was because Jews were permitted to perform their faith more openly than Muslims in the Crown of Aragon.

Although Eymeric certainly suspected that Jews might lead Christians into error in many ways, he nevertheless maintained that they should generally be allowed to practice the rites of their faith publicly. This was because those rites would often "signify" or "represent" some Christian truth, albeit indirectly. ${ }^{111}$ This harkened back to a standard medieval argument for the continued toleration of Jews, originating with the early church father Augustine of Hippo. He had reasoned that God had allowed Jews to survive into the era of the Christian dispensation because they served as witnesses to Christianity's own validity. ${ }^{12}$ Jews could perform this valuable function, however, only if they practiced Judaism properly according to Christian understanding. The fear was that any subtle deviance they introduced into their own practices might indirectly corrupt Christians. This justified inquisitorial oversight. I have already highlighted the strand of inquisitorial thought that argued the Talmud and other Jewish texts needed to be suppressed because they improperly or even heretically misrepresented certain fundamental truths found within Judaism itself.

Interestingly, traces of a similar attitude toward Muslim texts are evident in some of the traditions I have surveyed here. In the twelfth century, Peter the Venerable had declared that Islam, originally grounded at least partly in scripture, had come to be based more on what he termed "fables" about Muhammad's life, just as Judaism had come to be based on the Talmud rather than the Torah. ${ }^{113}$ Earlier still, the important Mozarabic text Liber denudationis, originally composed by an Iberian Christian most likely in Toledo in the late eleventh or early twelfth century, described how Muhammed's early followers had argued over the text of the Qur'an, ultimately excising

${ }^{109}$ Hill, Inquisition in the Fourteenth Century, 172-173 and 204-205, contrasts Eymeric to Gui in this regard.

${ }^{110}$ Karen Sullivan, The Inner Lives of Medieval Inquisitors (Chicago: University of Chicago Press, 2011), 172-180; and Castell Granados, "Inquisitor's Demons," 21-23.

${ }^{111}$ Eymeric, Directorium, 355 (2.46.13).

${ }^{112}$ Jeremy Cohen, Living Letters of the Law: Ideas of the Jew in Medieval Christianity (Berkeley: University of California Press, 1999), 23-65; and Paula Fredriksen, "Divine Justine and Human Freedom: Augustine on Jews and Judaism, 392-398," in From Witness to Witchcraft: Jews and Judaism in Medieval Christian Thought, ed. Jeremy Cohen (Wiesbaden: Harrassowitz, 1996), 29-54.

${ }^{113}$ Peter the Venerable, Contra sectam, 210; and Resnick, Writings, 151. On Peter's views regarding the corruption of the Talmud, see Irven M. Resnick, "Peter the Venerable on the Talmud, the Jews, and Islam," Medieval Encounters 24, no. 5-6 (2018): 510-529. 
many verses. ${ }^{114}$ This, too, could lead to the conclusion that what had originally been an at least partly valid tradition had become corrupted and needed to be carefully scrutinized by Christian authorities. Eymeric, however, shows how Christian concerns moved in a different direction.

While the rites and tenets of Judaism could impart some value to Christians, Eymeric estimated that those of Islam offered no such "utility." There was, therefore, no reason that Christian authorities should ever allow them to be performed publicly. They could, however, be tolerated inside any mosques that continued to exist in lands Christians had wrested from Muslim control or in private homes. ${ }^{115}$ This general position had been established more than a century earlier by the great Dominican theologian Thomas Aquinas. ${ }^{116}$ Eymeric explicated its particular consequences for inquisitorial action. Inquisitors did not need to police the private performance of Islam because it posed no danger of secretly corrupting the surrounding Christian population. Any subtle deviations that Muslims introduced into their practices, either maliciously or inadvertently, could only harm Muslims themselves. Conversely, any elements of Islam that might be enacted publicly were rendered automatically illicit. Christian authorities did not need to discern if they varied from some original truth that Christians ascribed to them in order to suppress them. There would, in short, be no need for any careful "examination and inquiry" (probatio et inquisitio), such as only expert inquisitors could provide. The only thing required was simple punishment whenever an act occurred outside of allotted private spaces. Even Eymeric, who broadly sought to champion the authority of the papacy and papally appointed inquisitors, concluded that jurisdiction over such straightforward matters could safely be left to secular princes. ${ }^{117}$

Certainly, Muslims could be suspected of secretly blaspheming the Christian God or desecrating Christian rites, just as Jews were. Nevertheless, Eymeric suggests why, within inquisitorial thought and perhaps that of Christian authorities more generally, Muslims were the focus of less concern than Jews. Because of Islam's different theological relationship to Christianity, Muslim practices required less precise scrutiny and control. Ironically, because they were shielded from Christian view, they represented less of the kind of hidden menace that inquisition was increasingly being used to expose.

\section{Conclusion}

Richard Southern once declared that "the existence of Islam was the most far-reaching problem in medieval Christendom." ${ }^{118} \mathrm{He}$ meant this primarily in terms of the stark geopolitical reality that the Islamic world presented to the Latin West. Conversely,

\footnotetext{
${ }^{114}$ Burman, Religious Polemic, 274-279.

${ }^{115}$ Eymeric, Directorium, 356 (2.46.13).

${ }^{116}$ Aquinas, Summa theologiae 2.2.10.11.

${ }^{117}$ Eymeric, Directorium, 356 (2.46.14): "Si autem fiant per modum per quem fieri prohibentur, hoc est publice et notorie, quod probatione et inquisitione non egeat, sed punitione, in isto casu praesenti statuto et ipso iure dominus noster Papa committit et remittit eos, ut punitionem et ultionem in eos exequatur, ad principes saeculares."

${ }^{118} \mathrm{R}$. W. Southern, Western Views of Islam in the Middle Ages (Cambridge, Mass.: Harvard University Press, 1962), 3. On the continued applicability of this judgment, see Daniel G. König, "Medieval Western European Perceptions of the Islamic World: From 'Active Othering' to the 'Voices in Between," in Christian-Muslims Relations: A Biographical History, vol. 4 (1200-1350), ed. David Thomas and Alexander Mallett, History of Christian-Muslim Relations 17 (Leiden: Brill, 2012), 17-28, at 18.
} 
his student R. I. Moore has suggested how Western clerical elites came to regard Jews as a more sinister threat lurking within Christendom. He saw this as part of the same dynamic that drove the identification and persecution of Christian heretics. ${ }^{119}$ Nicolau Eymeric's stance toward Muslims, particularly when compared to his stance toward Jews, seems to align with these different perceptions of threat. He clearly felt that Muslims could fall under inquisitorial jurisdiction in many ways. He articulated these more thoroughly than any previous medieval theorist of inquisition, and he argued against some contemporary opponents for an expansive notion of inquisitorial authority. Ultimately, however, while Jewish behavior required the kind of careful scrutiny that only trained inquisitors could provide (or at least that they were ideally suited to provide), he seems to have regarded the control of Muslims living within Christian society to be more generally a political problem, and he was content to leave such control to secular princes.

The labeling of Islam as, in its origin, a deviation from Christianity, and therefore fundamentally a Christian heresy, had always been more of an externally focused political statement than an internally directed legalistic one. Perhaps not surprisingly, then, in the fifteenth century, mainly in response to the political ascendency of the Ottoman Turks, a number of important Christian writers revived the notion of Islam as a heresy but paid no attention to Eymeric's more focused arguments, even when they clearly knew his work. Around 1460, for example, Nicholas of Cusa produced his Cribratio Alkorani at the request of Pope Pius II. In dedicating that work to the pontiff, he reasserted the old allegation that Islam arose out of Nestorian heresy, and he exhorted Pius to take action against Muslims just as Pope Leo I had against Nestorians a millennium before. ${ }^{120}$ Nicholas's friend Juan of Segovia was even more forceful. In his prologue to a new translation of the Qur'an, he repeatedly labeled Islam the greatest heresy that had ever existed, ${ }^{121}$ and in his De gladio divini spiritus, written in the 1450 s immediately after the fall of Constantinople, he described how Islam was rooted in Christian heresy through Muhammad's instruction by the heretical monk Sergius. ${ }^{122}$

\footnotetext{
${ }^{119}$ R. I. Moore, The Formation of a Persecuting Society: Authority and Deviance in Western Europe, 9501250, 2nd ed. (Oxford: Blackwell, 2007), 139-143.

${ }^{120}$ Jaspar Hopkins, Nicholas of Cusa's De pace fidei and Cribratio Alkorani: Translation and Analysis (Notre Dame, Ind.: University of Notre Dame Press, 1990), 75. See also Walter Andreas Euler, "A Critical Survey of Cusanus's Writings on Islam," in Nicholas of Cusa and Islam: Polemic and Dialogue in the Late Middle Ages, ed. Ian Christopher Levy, Rita George-Tvrtkonić, and Donald F. Duclow, Medieval and Reformation Traditions 183 (Leiden: Brill, 2014), 20-29, at 27-29; and Tristan Vigliano, Parler aux Musulmans: Quatre intellectuels face à l'Islam à l'orée de la Renaissance (Geneva: Droz, 2017), 151-207, esp. 155-156. On Nicholas's more tolerant approach in De pace fidei, see Joshua Hollmann, The Religious Concordance: Nicholas of Cusa and Christian-Muslim Dialogue, Studies in the History of Christian Traditions 185 (Leiden: Brill, 2017).

${ }^{121}$ José Martínez Gázquez, "El Prólogo de Juan de Segobia al Corán (Qur'ān) trilingüe (1456)," Mittellateinisches Jahrbuch 38 (2003): 389-410, at 394-396. On Juan's communication with Nicholas of Cusa, see Walter Andreas Euler, "L'image de l'Islam à la fin du Moyen Age: La correspondence entre Jean de Ségovie et Nicolas de Cues," in Nicolas de Cues et l'Islam, ed. Hervé Pasqua (Louvain-la-Neuve: Peeters, 2013), 9-20; or Walter Andreas Euler and Franz-Bernhard Stammkötter, "Johannes von Segovia und Nikolaus von Kues im Gespräch über den Islam," in Cusanus und der Islam, ed. Euler and Tom Kerger (Trier: Paulinus, 2010), 49-64.

${ }^{122}$ Juan de Segovia, De gladio divini spiritus in corda mittendo Sarracenorum: Edition und deutsche Übersetzung mit Einleitung und Erläuterungen, ed. and trans. Ulli Roth, 2 vols., Corpus Islamo-Christianum Series Latina 7 (Wiesbaden: Harrassowitz, 2012), 1:160, 1:342-346, 2:522.
} 
Juan owned a copy of Eymeric's Directorium, but he does not appear to have consulted it very much. ${ }^{123}$

Another famous fifteenth-century author, and a fellow inquisitor, relied heavily on Eymeric for other matters, but he too followed a different approach when addressing Islam. The German Dominican Heinrich Kramer (Institoris) drew extensively on Directorium inquisitorum when discussing the heretical nature of witchcraft in his infamous witch-hunting manual Malleus maleficarum, written in $1486 .{ }^{124}$ There he mentioned Muslims only in barest passing, noting that God was using the Turks to punish Christians just as he also used witches. ${ }^{125}$ Fifteen years later, however, Kramer afforded Islam more extensive treatment in his far less famous Sancte Romane ecclesie fidei defensionis clippeum. ${ }^{126}$ In that work, he repeatedly labeled Islam a heresy, and he reiterated such standard components of twelfth-century polemic as Muhammad's instruction by the heretical monk Sergius and that his teachings in the Qur'an were heretical against both Christianity and Judaism. ${ }^{127}$ Kramer also drew on thirteenth-century Dominican authorities on Islam, citing Thomas Aquinas's Summa contra gentiles and Riccoldo of Monte Croce's Contra legem Saracenorum in his general discussion of Islamic error. ${ }^{128}$ But he provided nary a reference to Nicolau Eymeric in this regard.

Ultimately, Eymeric's influence would prove inescapable, and Directorium inquisitorum would become "the best-known manual for inquisitors through the sixteenth and into the seventeenth century." ${ }^{29}$ During the Middle Ages, however, Muslims living under Christian rule were never thought to represent the same kind of potentially corrupting threat as Jews. This was not because there was no intellectual or legal apparatus to do so; Eymeric demonstrated that. Muslim communities were, of course, less widely dispersed across Europe. Even where they were numerous, as in the Crown of Aragon, they possessed less wealth and political importance than Jewish communities. Perhaps most deeply, though, while Christian Europe saw Islam as a looming external threat, Muslims within Christendom were not (yet) so readily imagined as the sort of conniving and duplicitous enemy within that was increasingly the focus of medieval inquisitorial thought.

Michael D. Bailey is a professor of history at Iowa State University.

\footnotetext{
${ }^{123}$ Benigno Hernández Montes, Biblioteca de Juan de Segovia: Edicion y comentario de su escritura de donacion (Madrid: Consejo Superior de Investigaciones Cientificas, 1984), 99, 248; although, see also Ann Marie Wolf, Juan de Segovia and the Fight for Peace: Christians and Muslims in the Fifteenth Century (Notre Dame, Ind.: University of Notre Dame Press, 2014), 205-206.

${ }^{124}$ Christopher S. Mackay, general introduction to Malleus maleficarum, by Henricus Institoris, OP, and Jacobus Sprenger, OP, ed. and trans. Christopher S. Mackay, 2 vols. (Cambridge: Cambridge University Press, 2006) 1:153.

${ }^{125}$ Institoris, Malleus maleficarum, 1:355-356 (1.15).

${ }^{126}$ Tamar Herzig, Christ Transformed into a Virgin Woman: Lucia Brocadelli, Heinrich Institoris, and the Defense of the Faith (Rome: Edizioni di storia e letteratura, 2013), esp. chap. 4.

${ }^{127}$ Henricus Institoris, Sancte Romane ecclesie fidei defensionis clippeum (Olomouc, 1501), fols. 86r, 91r.

${ }^{128}$ Institoris, Clippeum, fols. 86v, 91v, 92v; Riccoldo is misidentified as "Frater Nicolaus ordinis predicatorum," but Kramer cites the correct incipit for his Contra legem (fol. 91v).

${ }^{129}$ Edward Peters, Inquisition (Berkeley: University of California Press, 1989), 60. Although, on Eymeric's lesser immediate influence, see Heimann, "Nicolaus Eymerich OP," 150.
}

Cite this article: Bailey, Michael D. "Muslims in Medieval Inquisitorial Thought: Nicolau Eymeric and His Contexts." Church History 90, no. 1 (March 2021): 1-20. https://doi.org/10.1017/S0009640721000834. 